\title{
Vital capacity and COPD: the Swedish CArdioPulmonary biolmage Study (SCAPIS)
}

This article was published in the following Dove Press journal: International Journal of COPD

2 May 2016

Number of times this article has been viewed

Kjell Torén,' Anna-Carin Olin, ' Anne Lindberg, ${ }^{2}$ Jenny Vikgren, ${ }^{3}$ Linus Schiöler,' John Brandberg, ${ }^{3}$ Åse Johnsson, ${ }^{3}$ Gunnar Engström, ${ }^{4} \mathrm{H}$ Lennart Persson, ${ }^{5}$ Magnus Sköld, ${ }^{6}$ Jan Hedner, ${ }^{7}$ Eva Lindberg, ${ }^{8}$ Andrei Malinovschi, ${ }^{8}$ Eeva Piitulainen, ${ }^{9}$ Per Wollmer, ${ }^{9}$ Annika Rosengren, ${ }^{10}$ Christer Janson, ${ }^{8}$ Anders Blomberg, ${ }^{2}$ Göran Bergström ${ }^{10}$

'Section of Occupational and Environmental Medicine, Department of Molecular and Clinical Medicine, Institute of Medicine, Sahlgrenska Academy, University of Gothenburg, Gothenburg, ${ }^{2}$ Department of Public Health and Clinical Medicine, Division of Medicine/Respiratory Medicine, Umeå University, Umeå, ${ }^{3}$ Department of Radiology, Institute of Clinical Sciences, Sahlgrenska Academy, University of Gothenburg, Gothenburg, ${ }^{4}$ Department of Clinical Science, Malmö, Lund University, Lund, ${ }^{5}$ Department of Respiratory Medicine and Department of Medicine and Health Sciences, Linköping University, Linköping, ${ }^{6}$ Respiratory Medicine Unit, Department of Medicine Solna, Center for Molecular Medicine, Karolinska Institutet, Stockholm, ${ }^{7}$ Department of Internal Medicine/ Lung Medicine, Institute of Medicine, Sahlgrenska Academy, University of Gothenburg, Gothenburg, ${ }^{8}$ Department of Medical Sciences, Clinical Physiology and Respiratory, Allergy and Sleep Research, Uppsala University, Uppsala, ${ }^{9}$ Department of Translational Medicine, Lund University, Malmö, ${ }^{10}$ Department of Molecular and Clinical Medicine, Institute of Medicine, Sahlgrenska Academy, University of Gothenburg, Gothenburg, Sweden

Correspondence: Kjell Torén Department of Molecular and Clinical Medicine, Section of Occupational and Environmental Medicine, Institute of Medicine, Sahlgrenska Academy, University of Gothenburg, Box 4I4, S-405 30 Gothenburg, Sweden

Email kjell.toren@amm.gu.se
Background: Spirometric diagnosis of chronic obstructive pulmonary disease (COPD) is based on the ratio of forced expiratory volume in 1 second $\left(\mathrm{FEV}_{1}\right) /$ vital capacity $(\mathrm{VC})$, either as a fixed value $<0.7$ or below the lower limit of normal (LLN). Forced vital capacity (FVC) is a proxy for VC. The first aim was to compare the use of FVC and VC, assessed as the highest value of FVC or slow vital capacity (SVC), when assessing the $\mathrm{FEV}_{1} / \mathrm{VC}$ ratio in a general population setting. The second aim was to evaluate the characteristics of subjects with COPD who obtained a higher SVC than FVC.

Methods: Subjects $(\mathrm{n}=1,050)$ aged 50-64 years were investigated with $\mathrm{FEV}_{1}, \mathrm{FVC}$, and SVC after bronchodilation. Global Initiative for Chronic Obstructive Lung Disease (GOLD) COPD ${ }_{\mathrm{FVC}}$ was defined as $\mathrm{FEV}_{1} / \mathrm{FVC}<0.7$, GOLDCOPD ${ }_{\mathrm{vC}}$ as $\mathrm{FEV}_{1} / \mathrm{VC}<0.7$ using the maximum value of FVC or SVC, LLNCOPD $\mathrm{FVC}_{\text {C }}$ as $\mathrm{FEV}_{1} / \mathrm{FVC}$ below the LLN, and $\mathrm{LLNCOPD}_{\mathrm{VC}}$ as $\mathrm{FEV}_{1} / \mathrm{VC}$ below the LLN using the maximum value of FVC or SVC.

Results: Prevalence of GOLDCOPD ${ }_{\mathrm{FVC}}$ was $10.0 \%$ (95\% confidence interval [CI] 8.2-12.0) and the prevalence of $\operatorname{LLNCOPD}_{\mathrm{FVC}}$ was $9.5 \%(95 \% \mathrm{CI} 7.8-11.4)$. When estimates were based on VC, the prevalence became higher; $16.4 \%$ (95\% CI 14.3-18.9) and 15.6\% (95\% CI 13.5-17.9) for $\mathrm{GOLDCOPD}_{\mathrm{VC}}$ and $\mathrm{LLNCOPD}_{\mathrm{vC}}$, respectively. The group of additional subjects classified as having COPD based on $\mathrm{VC}$, had lower $\mathrm{FEV}_{1}$, more wheeze and higher residual volume compared to subjects without any COPD.

Conclusion: The prevalence of COPD was significantly higher when the ratio $\mathrm{FEV}_{1} / \mathrm{VC}$ was calculated using the highest value of SVC or FVC compared with using FVC only. Subjects classified as having COPD when using the VC concept were more obstructive and with indications of air trapping. Hence, the use of only FVC when assessing airflow limitation may result in a considerable under diagnosis of subjects with mild COPD.

Keywords: obstructive, epidemiology, general population, air trapping, spirometry, slow vital capacity, asthma

\section{Introduction}

Spirometry after bronchodilation is crucial in assessing the presence of airway obstruction, which is necessary for the diagnosis of chronic obstructive pulmonary disease (COPD). ${ }^{1}$ Chronic airway obstruction is mostly assessed using the ratio of forced expiratory volume in 1 second $\left(\mathrm{FEV}_{1}\right) /$ forced vital capacity $(\mathrm{FVC})<0.7$. In this ratio, FVC is used as a substitute for vital capacity (VC). An often overlooked problem is whether FVC can be used as an appropriate approximation of VC. VC is obtained by using the maximum value of either FVC or slow vital capacity (SVC). In the European Respiratory Society (ERS) statement from 1995, the recommendation is to use the maximum value of either FVC or SVC as an estimate of VC, ${ }^{2}$ and this was kept in the joint American Thoracic Society (ATS)/ERS Task Force report. ${ }^{3}$ The 
most recent Global Initiative for Chronic Obstructive Lung Disease (GOLD) document recommends the use of FVC, even if the use of SVC is acknowledged, especially among subjects with obstructive airway diseases. ${ }^{1}$ In the official ATS document on spirometry in occupational settings, only FVC is considered. ${ }^{4}$

Spirometry is heavily patient-dependent and also dependent on the skills of the testing personnel. Among subjects with air trapping, FVC may be incomplete, resulting in higher $\mathrm{FEV}_{1} / \mathrm{FVC}$ ratio. However, in clinical practice, as well as in epidemiological studies, the use of only FVC is common. The underlying assumption is that FVC is a valid measurement of $\mathrm{VC}$ because there is thought to be little difference between SVC and FVC in unselected populations. Furthermore, in recent applications of the GOLD statements, the use of VC is not mentioned. ${ }^{5-7}$ In the most recent ATS/ERS statement, FVC is considered to be a suitable surrogate for $\mathrm{VC}{ }^{7}$

There is also a complete lack of general population-based studies investigating the effect of using VC based on the best value of SVC or FVC, instead of only employing FVC. There are few studies in clinical populations, and the largest one is a Swedish study of subjects who took sick leave and were current smokers. In this selected group, the prevalence of COPD increased from $14.0 \%$ to $16.8 \%$ when $\mathrm{VC}$ was used instead of only using $\mathrm{FVC}$ in the calculation of the $\mathrm{FEV}_{1} / \mathrm{VC}$ ratio. ${ }^{8}$

Further, the GOLD recommendations of the use of the fixed ratio of $\mathrm{FEV}_{1} / \mathrm{FVC}<0.7$ have been challenged because such an approach does not take into account age-related changes in lung function. ${ }^{9}$ Using a definition based on an $\mathrm{FEV}_{1} / \mathrm{FVC}<0.7$ may cause overestimation of COPD in the older population in epidemiological studies. ${ }^{10}$ An alternative approach to the use of the fixed ratio of $\mathrm{FEV}_{1} / \mathrm{FVC}<0.7$ is to use the lower limit of normal (LLN) as a cut-off. The LLN is calculated using the distribution in reference material adjusted for age, sex, and height. In 1993, the ERS recommended the use of cut-off values of $\mathrm{FEV}_{1} / \mathrm{VC}$ adjusted for age and sex; $88 \%$ for females and $89 \%$ for males. ${ }^{11}$ These values corresponded to the LLN and their use has been jointly recommended by the ATS and the ERS in clinical practice and in epidemiological studies. ${ }^{3}$

The first aim of this study was to compare the use of FVC and VC, assessed as the highest value of FVC or SVC, when assessing the $\mathrm{FEV}_{1} / \mathrm{VC}$ ratio in a general population setting.

The second aim was to evaluate the characteristics of subjects with COPD who obtained a higher SVC than FVC.

\section{Materials and methods}

The study data were derived from the Swedish CArdioPulmonary bioImage Study (SCAPIS). SCAPIS is a national
Swedish general population study aiming to include 30,000 subjects aged 50-64 years. The study design has been extensively described elsewhere. ${ }^{12}$ This study is from the first part of the SCAPIS, the pilotSCAPIS, and was performed at Sahlgrenska University Hospital in Gothenburg, Sweden in 2012. This study was approved by The Regional Committee of Ethics in Umeå, 2010/228-31, and all included subjects gave their written consent to participate in the study. Briefly, a randomly selected population sample including 2,243 adults aged 50-64 years were selected from the census register. Among these, 1,111 subjects agreed to participate. All of the subjects answered a respiratory questionnaire comprising the Medical Research Council scale, which includes five grades for assessing dyspnea, along with items about smoking habits and socioeconomic status. ${ }^{13}$ A venous blood sample $(100 \mathrm{~mL})$ was taken from each subject and for the purpose of this study, analyses of high-sensitive C-reactive protein and hemoglobin were performed.

Dynamic spirometry, including $\mathrm{FEV}_{1}, \mathrm{FVC}$, and SVC, was performed. ${ }^{14}$ Static lung volumes were measured according to ATS/ERS standards using two measurements of total lung capacity (TLC) and residual volume (RV). All spirometric maneuvers were performed before and 15 minutes after inhalation of $400 \mu \mathrm{g}$ of salbutamol using a nose clamp with the subject in the sitting position. Gas diffusing capacity $\left(\mathrm{TL}_{\mathrm{CO}}\right)$ was measured using a single breath carbon monoxide diffusion test. ${ }^{15}$ A Jaeger Master Screen PFT (Hoechberg, Germany) was used for all measurements. Predicted values of $\mathrm{FEV}_{1}$ and $\mathrm{FVC}$ were based on a recent Swedish population. ${ }^{16}$ The predicted values for TLC, RV, and $\mathrm{TL}_{\mathrm{CO}}$ were based on published equations. ${ }^{17-19}$ In addition, $\mathrm{TL}_{\mathrm{CO}}$ was adjusted for hemoglobin. ${ }^{15}$ All lung function values were recorded after bronchodilation, and are generally expressed as percent predicted ( $\%$ predicted).

\section{Definitions}

While FVC refers to FVC alone, the VC measurement is taken from whichever value that is higher, FVC or SVC.

$\mathrm{GOLDCOPD}_{\mathrm{FVC}}$ was defined as the ratio of $\mathrm{FEV}_{1} / \mathrm{FVC}<0.7$ using $\mathrm{FEV}_{1}$ and FVC. GOLDCOPD $\mathrm{VC}_{\mathrm{C}}$ was defined as the ratio of $\mathrm{FEV}_{1} / \mathrm{VC}<0.7$ using $\mathrm{VC}$ defined as the highest value of FVC or SVC. GOLDCOPD ${ }_{\mathrm{VC}>\mathrm{FVC}}$ comprised subjects with GOLDCOPD $_{\mathrm{VC}}$, but not with GOLDCOPD $\mathrm{FVC}$ LLNCOPD $_{\mathrm{FVC}}$ was defined as the ratio $\mathrm{FEV}_{1} / \mathrm{FVC}$ below the LLN using FVC. LLNCOPD $_{\mathrm{VC}}$ was defined as the ratio of $\mathrm{FEV}_{1} / \mathrm{VC}$ below the LLN using VC defined as the highest value of FVC or SVC. Severity of COPD in subjects with GOLDCOPD ${ }_{\mathrm{FVC}}$ and GOLDCOPD ${ }_{\mathrm{VC}}$ was classified in different stages based on $\mathrm{FEV}_{1} \%$ predicted. $^{1}$ 
The non-COPD group was defined as subjects without COPD, which is, not having any of GOLDCOPD ${ }_{\mathrm{FVC}}$, GOLDCOPD $_{\mathrm{VC}}$, LLNCOPD ${ }_{\mathrm{VC}}$, or LLNCOPD $\mathrm{FVC}$.

Physician-diagnosed asthma was defined as an affirmative answer to "Have you ever had asthma diagnosed by a physician?"20 Chronic bronchitis was defined as an affirmative answer to "Have you had long-standing cough with phlegm?" and "If so, did any period last at least 3 months?" and "If so, have you had such periods at least 2 years in a row?"

Smoking was categorized as current smokers, former smokers, or never-smokers. Former smokers were defined as those who have smoked for at least 1 year, but not during the last year. Socioeconomic status was defined according to the highest education in three groups: university education (high), high school (medium), and elementary school or not completed school (low). Height and weight were based on measured values, and body mass index was defined as measured weight/height ${ }^{2}$.

\section{Statistics}

All calculations were performed using SAS version 9.2 (SAS Institute, Cary, NC, USA). Categorical variables were compared using the $\chi^{2}$ test to identify significant associations. A $P$-value $<0.05$ was considered significant. The $95 \%$ confidence intervals (CIs) for prevalences were calculated using exact methods.

Multivariate logistic regression modeling was used, assuming a basic model comprising age, sex, and smoking and with independent variables selected a priori. The final model was the results of backward selection, with a limit of $P<0.25$. All results from the logistic regression models are expressed as odds ratios (ORs) with 95\% CIs.

\section{Results}

Of the 1,111 individuals participating in the clinical investigations, 61 were excluded because of incomplete data regarding smoking habits or spirometry, resulting in a final study population of 1,050 subjects. Basic data on sex, smoking, and prevalence of COPD according to different definitions are shown in Table 1. Current smokers, especially males, had a higher prevalence of COPD, regardless of the definition of COPD.

In this study population aged 50-64 years, the prevalence of GOLDCOPD ${ }_{\mathrm{FVC}}$ was similar $(10.0 \%, 95 \%$ CI 8.2-12.0) to the prevalence of $\operatorname{LLNCOPD}_{\mathrm{FVC}}(9.5 \%, 95 \%$ CI 7.8-11.4). When estimates were based on VC (instead of FVC), the prevalence of GOLDCOPD ${ }_{\mathrm{vC}}$ became higher $(16.4 \%, 95 \% \mathrm{CI}$ 14.3-18.9) and that of $\mathrm{LLNCOPD}_{\mathrm{VC}}$ became higher $(15.6 \%$, $95 \%$ CI 13.5-17.9). The prevalence of GOLDCOPD ${ }_{\mathrm{VC}}$ was higher than the prevalence of GOLDCOPD FVC $(16.4 \%$ vs $10.0 \%, P<0.05)$. Similarly, the prevalence of $\mathrm{LLNCOPD}_{\mathrm{vc}}$ was higher than the prevalence of $\operatorname{LLNCOPD}_{\mathrm{FVC}}(15.6 \% \mathrm{vs}$ $9.5 \%, P<0.05)$.

Basic data regarding age, anthropometry, hemoglobin, high-sensitive C-reactive protein, and lung function results are shown in Table 2 according to different definitions of COPD. Cross-tabulations of different definitions of COPD are shown in Table 3. It is shown that COPDGOLD $\mathrm{vc}$ is a more sensitive definition than $\mathrm{COPDGOLD}_{\mathrm{FVC}}$, as

Table I Prevalence (\%) of COPD according to different spirometric definitions in pilot SCAPIS according to sex and smoking habits

\begin{tabular}{|c|c|c|c|c|c|c|c|c|c|}
\hline \multirow[t]{2}{*}{$\begin{array}{l}\text { Investigated } \\
\text { groups }\end{array}$} & \multicolumn{3}{|l|}{$\begin{array}{l}\text { All } \\
n=I, 050\end{array}$} & \multicolumn{2}{|c|}{$\begin{array}{l}\text { Never-smokers } \\
\mathrm{n}=\mathbf{4 4 8}\end{array}$} & \multicolumn{2}{|c|}{$\begin{array}{l}\text { Ex-smokers } \\
n=415\end{array}$} & \multicolumn{2}{|c|}{$\begin{array}{l}\text { Current smokers } \\
\mathrm{n}=187\end{array}$} \\
\hline & $\begin{array}{l}\text { All } \\
n=I, 050\end{array}$ & $\begin{array}{l}M \\
n=525\end{array}$ & $\begin{array}{l}F \\
n=525\end{array}$ & $\begin{array}{l}M \\
n=217\end{array}$ & $\begin{array}{l}F \\
n=23 I\end{array}$ & $\begin{array}{l}M \\
n=220\end{array}$ & $\begin{array}{l}F \\
n=195\end{array}$ & $\begin{array}{l}M \\
n=88\end{array}$ & $\begin{array}{l}F \\
n=99\end{array}$ \\
\hline \multirow[t]{2}{*}{ Non-COPD } & $83.1 \%$ & $80.6 \%$ & $85.7 \%$ & $88.5 \%$ & $92.6 \%$ & $79.6 \%$ & $82.1 \%$ & $63.6 \%$ & $76.8 \%$ \\
\hline & $n=873$ & $n=423$ & $n=450$ & $n=192$ & $n=2 \mid 4$ & $\mathrm{n}=175$ & $n=160$ & $\mathrm{n}=56$ & $n=76$ \\
\hline \multirow[t]{2}{*}{$\mathrm{GOLDCOPD}_{\mathrm{FVC}}$} & $10.0 \%^{\mathrm{a}}$ & $11.4 \%^{\mathrm{a}}$ & $8.6 \%^{\mathrm{a}}$ & $4.6 \%$ & $4.8 \%$ & $10.9 \%$ & $9.7 \%^{a}$ & $29.6 \%$ b,c & $15.2 \%$ \\
\hline & $\mathrm{n}=105$ & $\mathrm{n}=60$ & $\mathrm{n}=45$ & $\mathrm{n}=10$ & $\mathrm{n}=11$ & $\mathrm{n}=24$ & $n=19$ & $\mathrm{n}=26$ & $\mathrm{n}=15$ \\
\hline \multirow[t]{2}{*}{ GOLDCOPD $_{\mathrm{vc}}$} & $16.4 \%$ & $19.0 \%$ & $13.9 \%$ & $10.6 \%$ & $6.9 \%$ & $20.5 \%$ & $17.4 \%$ & $36.4 \% \mathrm{~b}, \mathrm{c}$ & $23.2 \%$ \\
\hline & $\mathrm{n}=173$ & $n=100$ & $\mathrm{n}=73$ & $\mathrm{n}=23$ & $n=16$ & $\mathrm{n}=45$ & $\mathrm{n}=34$ & $\mathrm{n}=32$ & $\mathrm{n}=23$ \\
\hline \multirow{2}{*}{$\mathrm{GOLDCOPD}_{\mathrm{VC}>\mathrm{FVC}}$} & $6.5 \%$ & $7.6 \%$ & $5.3 \%$ & $6.0 \%$ & $2.2 \%$ & $9.6 \%$ & $7.7 \%$ & $6.8 \%$ & $8.1 \%$ \\
\hline & $n=68$ & $\mathrm{n}=40$ & $\mathrm{n}=28$ & $n=13$ & $n=5$ & $n=21$ & $n=15$ & $n=6$ & $\mathrm{n}=8$ \\
\hline \multirow[t]{2}{*}{ LLNCOPD $_{\mathrm{FVC}}$} & $9.5 \%$ & $10.8 \%$ & $8.2 \%$ & $5.1 \%$ & $3.9 \%$ & $10.4 \%$ & $9.2 \%$ & $26.1 \% \mathrm{~b}$ & $16.2 \%$ \\
\hline & $n=100$ & $n=57$ & $n=43$ & $\mathrm{n}=1 \mathrm{I}$ & $n=9$ & $n=23$ & $\mathrm{n}=18$ & $n=23$ & $n=16$ \\
\hline \multirow[t]{2}{*}{$\mathrm{LLNCOPD}_{\mathrm{vc}}$} & $15.6 \%$ & $18.0 \%$ & $13.1 \%$ & $11.1 \%$ & $6.1 \%$ & $17.7 \%$ & $16.9 \%$ & $36.4 \%$ b,c & $22.2 \%^{\mathrm{b}}$ \\
\hline & $n=164$ & $n=95$ & $n=69$ & $\mathrm{n}=24$ & $n=14$ & $n=39$ & $n=33$ & $n=32$ & $n=22$ \\
\hline
\end{tabular}

Notes: ${ }^{a} P<0.05$, GOLDCOPD $_{\mathrm{FVC}}$ vs GOLDCOPD ${ }_{\mathrm{VC}}$; ${ }^{\mathrm{P}}<<0.05$, current smokers vs never-smokers; ${ }^{c}<<0.05$, males vs females. GOLDCOPD ${ }_{\mathrm{FVC}}$ was defined as the ratio of $\mathrm{FEV}_{1} / \mathrm{FVC}<0.7$ using $\mathrm{FEV}_{1}$ and FVC. GOLDCOPD $\mathrm{vC}_{\mathrm{VC}}$ was defined as the ratio of $\mathrm{FEV}_{1} / \mathrm{VC}<0.7$ using VC defined as the highest value of FVC or $\mathrm{SVC}$. GOLDCOPD $\mathrm{V}_{\mathrm{VC}>\mathrm{FVC}}$ comprised subjects with GOLDCOPD as the ratio of $F E V, / V C$ below the LLN using VC defined as the highest value of FVC or SVC.

Abbreviations: COPD, chronic obstructive pulmonary disease; F, female; FVC, forced vital capacity; GOLD, Global Initiative for Chronic Obstructive Lung Disease; LLN, lower limit of normal; M, male; SCAPIS, Swedish CArdioPulmonary biolmage Study; VC, vital capacity. 
Table 2 Age, anthropometric data, hemoglobin, high specific CRP, and lung function values in I,050 subjects in pilotSCAPIS according to different spirometric definitions of COPD

\begin{tabular}{|c|c|c|c|c|c|}
\hline Characteristics & $\begin{array}{l}\text { All } \\
(n=I, 050)\end{array}$ & $\begin{array}{l}\text { Non-COPD } \\
(n=873)\end{array}$ & $\begin{array}{l}\text { GOLDCOPD }_{\mathrm{FVC}} \\
(\mathrm{n}=105)\end{array}$ & $\begin{array}{l}\text { GOLDCOPD }_{\mathrm{vc}} \\
(\mathrm{n}=173)\end{array}$ & $\begin{array}{l}\text { GOLDCOPD }_{\mathrm{vC}>\mathrm{FVC}} \\
(\mathrm{n}=68)\end{array}$ \\
\hline Age (years) & $57.3(0.14)$ & $57.1(0.15)$ & $58.7(0.41)^{\mathrm{a}}$ & $58.4(0.34)^{\mathrm{a}}$ & $57.9(0.58)$ \\
\hline Males & $50.0 \%(n=525)$ & $48.5 \%(n=423)$ & $57.1 \%(n=60)$ & $57.8 \%^{\mathrm{a}}(\mathrm{n}=100)$ & $58.8 \%(n=40)$ \\
\hline High SES (\%) & $37.4 \%$ & $38.8 \%$ & $24.8 \%^{\mathrm{a}}$ & $29.5 \%^{\mathrm{a}}$ & $36.8 \%$ \\
\hline Weight (kg) & $80.5(0.48)$ & $80.0(0.51)$ & $81.5(1.70)$ & $83.0(1.34)$ & $85.4(2.16)^{\mathrm{a}}$ \\
\hline Height $(\mathrm{cm})$ & $171.6(0.30)$ & $171.3(0.32)$ & $172.9(0.96)$ & $173.2(0.78)$ & $173.7(1.31)$ \\
\hline BMI $\left(\mathrm{kg} / \mathrm{m}^{2}\right)$ & $27.3(0.14)$ & $27.2(0.15)$ & $27.2(0.50)$ & $27.6(0.38)$ & $28.2(0.57)$ \\
\hline $\mathrm{Hb}(g / L)$ & $140.6(0.38)$ & $140.2(0.42)$ & $142.3(1.20)$ & $142.7(0.92)$ & $143.3(1.45)^{\mathrm{a}}$ \\
\hline CRP & $2.3(0.11)$ & $2.2(0.11)$ & $3.2(0.44)^{\mathrm{a}}$ & $2.8(0.34)^{\mathrm{a}}$ & $2.2(0.52)^{\mathrm{b}}$ \\
\hline $\mathrm{FEV}_{\text {, }}(\%$ pred $)$ & $99.9(0.7 I)$ & $102.3(0.75)$ & $83.1(2.17)^{\mathrm{a}}$ & $87.6(1.79)^{\mathrm{a}}$ & $94.5(2.91)^{\mathrm{a}}$ \\
\hline FVC (\% pred) & $100.5(0.73)$ & $100.3(0.79)$ & $100.6(2.38)$ & $101.0(1.94)$ & $101.6(3.33)$ \\
\hline $\mathrm{FEV}_{1} / \mathrm{FVC}$ & $0.78(0.0020)$ & $0.80(0.0015)$ & $0.64(0.0059)^{\mathrm{a}}$ & $0.68(0.0049)^{\mathrm{a}}$ & $0.73(0.0027)^{\mathrm{a}, \mathrm{b}}$ \\
\hline $\mathrm{K}_{\mathrm{co}}(\%$ pred $)$ & $93.8(1.16)$ & $94.3(1.26)$ & $91.0(5.0)$ & $92.7(1.46)$ & $91.3(2.50)$ \\
\hline $\mathrm{TL}_{\mathrm{co}}(\%$ pred $)$ & $100.0(0.47)$ & $96.6(0.48)$ & $89.5(2.03)^{\mathrm{a}}$ & $84.8(1.9)^{\mathrm{a}}$ & $97.5(1.86)$ \\
\hline $\mathrm{TL}_{\mathrm{co}}-\mathrm{Hb}$ adjusted (\% pred) & $99.4(0.36)$ & $99.7(0.35)$ & $96.5(1.72)$ & $98.0(1.23)$ & $100.3(1.85)$ \\
\hline TLC (\% pred) & II $0.3(0.57)$ & $109.2(0.60)$ & $116.5(2.22)^{\mathrm{a}}$ & $116.3(1.65)^{\mathrm{a}}$ & I $6.0(2.44)^{\mathrm{a}}$ \\
\hline RV (\% pred) & $104.4(0.69)$ & $102.0(0.7 \mid)$ & $118.4(2.70)^{a}$ & II7.I (I.94) & II $5.2(2.73)^{\mathrm{a}}$ \\
\hline
\end{tabular}

Notes: Values are mean $\pm(\mathrm{SE})$, unless otherwise specified. a $P<0.05$, compared with non-COPD subjects. ${ }^{\mathrm{b} P}<0.05, \mathrm{GOLDCOPD}_{\mathrm{VC}>\mathrm{FVC}} \mathrm{Vs}_{\mathrm{GO}} \mathrm{GOLCOPD}_{\mathrm{FVC}} \mathrm{GOLDCOPD}_{\mathrm{FVC}}$ was defined as the ratio of $F E V, / F V C<0.7$ using FEV, and FVC. GOLDCOPD ${ }_{V C}$ was defined as the ratio of FEV $/$ NC $<0.7$ using VC defined as the highest value of FVC or SVC. GOLDCOPD ${ }_{\mathrm{VC}>\mathrm{FVC}}$ comprised subjects with $\mathrm{GOLDCOPD}_{\mathrm{VC}}$, but not with GOLDCOPD $\mathrm{FVC}$.

Abbreviations: BMI, body mass index; COPD, chronic obstructive pulmonary disease; CRP, C-reactive protein; FEV vital capacity; $\mathrm{K}_{\mathrm{co}}$, transfer coefficient; $\mathrm{TL}_{\mathrm{co}}$, gas diffusing capacity; GOLD, Global Initiative for Chronic Obstructive Lung Disease; pred, predicted; Hb, hemoglobin; RV, residual volume; SCAPIS, Swedish CArdioPulmonary biolmage Study; SE, standard error; SES, socioeconomic status; TLC, total lung capacity; VC, vital capacity.

only $60.7 \%$ of COPDGOLD ${ }_{\mathrm{VC}}$ cases are identified by the COPDGOLD ${ }_{\mathrm{FVC}}$ definition.

The distribution of different stages of severity among different groups of COPD is shown in Table 4. In this general population sample, no subjects were in COPD GOLD stage 4. Subjects with $\mathrm{COPD}_{\mathrm{FVC}}$ or $\mathrm{COPD}_{\mathrm{VC}}$ had an increased prevalence of dyspnea, wheezing, chronic bronchitis, and physician-diagnosed asthma compared to the non-COPD group (Table 5). The prevalence of respiratory conditions was lower in subjects with GOLDCOPD ${ }_{\mathrm{VC}>\mathrm{FVC}}$ but there were no significant differences compared with the nonCOPD group.

Sixty-eight subjects were classified as having GOLD$\mathrm{COPD}_{\mathrm{VC}>\mathrm{FVC}}$ and in univariate analyses, these subjects with

Table 3 Cross-tabulation of different spirometric definitions of COPD in pilotSCAPIS

\begin{tabular}{llll}
\hline $\begin{array}{l}\text { COPD } \\
\text { definitions }\end{array}$ & GOLDCOPD $_{\mathrm{FVC}}$ & GOLDCOPD $_{\mathrm{vc}}$ & LLNCOPD $_{\mathrm{FVC}}$ \\
\hline All & 105 & 173 & 100 \\
GOLDCOPD $_{\mathrm{FVC}}$ & - & $105(60.7 \%)$ & $92(92.0 \%)$ \\
GOLDCOPD $_{\mathrm{VC}}$ & $105(100.0 \%)$ & - & $100(100.0 \%)$ \\
LLNCOPD $_{\mathrm{FVC}}$ & $92(87.6 \%)$ & $100(57.8 \%)$ & - \\
\hline
\end{tabular}

Abbreviations: COPD, chronic obstructive pulmonary disease; FVC, forced vital capacity; GOLD, Global Initiative for Chronic Obstructive Lung Disease; LLN, lower limit of normal; SCAPIS, Swedish CArdioPulmonary biolmage Study; VC, vital capacity.
GOLDCOPD $_{\mathrm{VC}>\mathrm{FVC}}$ had higher weight, higher hemoglobin, lower $\mathrm{FEV}_{1}$, more obstruction and higher RV and TLC compared to the non-COPD group (Table 2). In logistic regression, with GOLDCOPD ${ }_{\mathrm{VC}>\mathrm{FVC}}$ vs non-COPD as the dependent variable, there were significant associations with age (OR 1.08, 95\% CI 1.01-1.15), wheeze (OR 2.3, 95\% CI $1.05-4.9)$, decreased $\mathrm{FEV}_{1}(\mathrm{OR} 0.82,95 \% \mathrm{CI} 0.78-0.86)$ and increased FVC (OR 1.19, 95\% CI 1.14-1.24 and increased RV (OR 1.02, 95\% CI 1.01-1.04) (Table 6).

\section{Discussion}

The most important findings in this general population-based study were that the prevalence of COPD, defined as the presence of airflow limitation, was significantly higher when

Table 4 Prevalence (\%) of COPD according to different stages according to the GOLD criteria in pilotSCAPIS

\begin{tabular}{llllll}
\hline $\begin{array}{l}\text { COPD } \\
\text { definitions }\end{array}$ & $\begin{array}{l}\text { All, } \\
\mathbf{n}\end{array}$ & $\begin{array}{l}\text { Stage I, } \\
\mathbf{n}(\%)\end{array}$ & $\begin{array}{l}\text { Stage 2, } \\
\mathbf{n}(\%)\end{array}$ & $\begin{array}{l}\text { Stage 3, } \\
\mathbf{n}(\%)\end{array}$ & $\begin{array}{l}\text { Stage 4, } \\
\mathbf{n}(\%)\end{array}$ \\
\hline GOLDCOPD $_{\mathrm{FVC}}$ & $\mathrm{I} 05$ & $53(50.5)$ & $47(44.8)$ & $5(4.8)$ & 0 \\
GOLDCOPD $_{\mathrm{VC}}$ & 173 & $98(56.6)$ & $69(39.9)$ & $6(3.5)$ & 0 \\
GOLDCOPD $_{\mathrm{VC}>\mathrm{FVC}}$ & 68 & $45(66.2)$ & $22(32.3)$ & $\mathrm{I}(1.5)$ & 0 \\
\hline
\end{tabular}

Abbreviations: COPD, chronic obstructive pulmonary disease; FVC, forced vital capacity; GOLD, Global Initiative for Chronic Obstructive Lung Disease; SCAPIS, Swedish CArdioPulmonary biolmage Study; VC, vital capacity. 
Table 5 Comparison of the prevalence of dyspnea (according to MRC dyspnea scale), chronic bronchitis, asthma, and wheeze in relation to different spirometric definitions of COPD

\begin{tabular}{|c|c|c|c|c|c|}
\hline Covariates (questionnaire-based) & $\begin{array}{l}\text { All } \\
n=I, 052\end{array}$ & $\begin{array}{l}\text { Non-COPD } \\
n=873\end{array}$ & $\begin{array}{l}\text { GOLD } \\
\text { COPD }_{\mathrm{FVC}} \\
\mathrm{n}=105\end{array}$ & $\begin{array}{l}\text { GOLD } \\
\text { COPD }_{\mathrm{vc}} \\
\mathrm{n}=173\end{array}$ & $\begin{array}{l}\text { GOLD } \\
\text { COPD }_{\mathrm{vc}>\mathrm{FVC}} \\
(\mathrm{n}=68)\end{array}$ \\
\hline \multirow[t]{2}{*}{ MRC grade I } & $4.4 \%$ & $3.6 \%$ & $11.1 \%{ }^{\mathrm{a}}$ & $8.6 \%^{\mathrm{a}}$ & $4.7 \%$ \\
\hline & $n=45$ & $n=31$ & $\mathrm{n}=\mathrm{I} \mid$ & $\mathrm{n}=14$ & $\mathrm{n}=3$ \\
\hline \multirow[t]{2}{*}{ MRC $>$ grade I } & $6.0 \%$ & $4.6 \%$ & $15.1 \%^{\mathrm{a}}$ & $12.2 \%^{\mathrm{a}}$ & $7.9 \%$ \\
\hline & $n=60$ & $\mathrm{n}=40$ & $\mathrm{n}=15$ & $\mathrm{n}=20$ & $n=5$ \\
\hline \multirow[t]{2}{*}{ Chronic bronchitis } & $7.2 \%$ & $6.5 \%$ & $12.4 \%^{\mathrm{a}}$ & $10.4 \%$ & $7.3 \%$ \\
\hline & $(n=76)$ & $(n=57)$ & $\mathrm{n}=13$ & $\mathrm{n}=18$ & $\mathrm{n}=5$ \\
\hline \multirow[t]{2}{*}{ Physician-diagnosed asthma } & $9.2 \%$ & $7.3 \%$ & $21.9 \%$ & $18.5 \%^{\mathrm{a}}$ & $13.2 \%$ \\
\hline & $n=97$ & $(n=64)$ & $\mathrm{n}=23$ & $\mathrm{n}=32$ & $n=9$ \\
\hline \multirow[t]{2}{*}{ Wheeze } & $8.6 \%$ & $5.6 \%$ & $28.6 \%{ }^{\mathrm{a}}$ & $23.1 \%^{\mathrm{a}}$ & $14.7 \%$ \\
\hline & $\mathrm{n}=90$ & $(n=49)$ & $\mathrm{n}=30$ & $\mathrm{n}=40$ & $n=10$ \\
\hline
\end{tabular}

Note: ${ }^{a} P<0.05$, compared with non-COPD subjects.

Abbreviations: COPD, chronic obstructive pulmonary disease; FVC, forced vital capacity; GOLD, Global Initiative for Chronic Obstructive Lung Disease; MRC, Medical Research Council; VC, vital capacity.

the ratio $\mathrm{FEV}_{1} / \mathrm{VC}$ was calculated using the highest value of SVC or FVC compared with using FVC only. This was independent of whether the GOLD or the LLN definition of COPD was applied. Additional subjects who were identified as having COPD when applying the VC approach compared with the FVC approach $\left(\mathrm{GOLDCOPD}_{\mathrm{VC}>\mathrm{FVC}}\right)$ were less obstructed than the remaining subjects with COPD. Still, these additional subjects had decreased $\mathrm{FEV}_{1}$ and increased $\mathrm{RV}$, indicating presence of obstruction and air trapping, compared to healthy subjects. These results underscore that the use of only FVC when assessing airflow limitation may result in a considerable underdiagnosis of subjects with mild COPD.

We observed a significantly higher prevalence of COPD, defined as the presence of postbronchodilator airflow limitation, when including the highest value of FVC or SVC as

Table 6 Logistic regression models of GOLDCOPD ${ }_{\mathrm{VC}>\mathrm{FVC}}$ vs non-COPD as the dependent variable

\begin{tabular}{|c|c|c|c|}
\hline Independent variables & $\begin{array}{l}\text { Odds } \\
\text { ratio }\end{array}$ & $\begin{array}{l}95 \% \text { confidence } \\
\text { interval }\end{array}$ & $P$-value \\
\hline Sex ${ }^{a}$ & 1.6 & $0.9-2.7$ & 0.11 \\
\hline Age (years) & 1.08 & $1.01-1.15$ & 0.03 \\
\hline Current smokers ${ }^{\mathrm{b}}$ & 1.6 & $0.7-3.3$ & 0.23 \\
\hline Never-smokers ${ }^{\mathrm{b}}$ & 0.6 & $0.3-1.2$ & 0.16 \\
\hline Physician-diagnosed asthma ${ }^{b}$ & 1.7 & $0.8-3.8$ & 0.19 \\
\hline Wheeze $^{\mathrm{b}}$ & 2.3 & $1.05-4.9$ & 0.04 \\
\hline FEV (\% predicted) & 0.82 & $0.78-0.86$ & $<0.001$ \\
\hline FVC (\% predicted) & 1.19 & $1.14-1.24$ & $<0.001$ \\
\hline RV (\% predicted) & 1.02 & $1.01-1.04$ & $<0.001$ \\
\hline
\end{tabular}

Notes: a Males $=\mathrm{I}$, females $=0$. ${ }^{\mathrm{b}} \mathrm{I}=$ Yes, $0=$ No.

Abbreviations: COPD, chronic obstructive pulmonary disease; $\mathrm{FEV}_{1}$, forced expiratory volume in I second; FVC, forced vital capacity; GOLD, Global Initiative for Chronic Obstructive Lung Disease; RV, residual volume; VC, vital capacity. the denominator when calculating the $\mathrm{FEV}_{1} / \mathrm{VC}$ ratio. This important aspect has mostly been neglected in previous studies, but there are some exceptions. In a Portuguese study of a clinical population, it was observed that the prevalence of airway obstruction (COPD) increased from $43.9 \%$ when using FVC to $52.2 \%$ when using $\mathrm{SVC}$ as the denominator. ${ }^{21}$ In a Swedish study of sick-listed subjects who were current smokers, the prevalence of COPD according to the GOLD guidelines increased from $14.0 \%$ to $16.8 \%$ when the best value of FVC or SVC was used in the calculation of the $\mathrm{FEV}_{1} /$ $\mathrm{VC}$ ratio compared with only using $\mathrm{FVC} .{ }^{8}$ When applying the LLN approach among these smokers, the prevalence of COPD increased from $17.6 \%$ to $21.7 \%$.

In our study, when applying the maximum value of $\mathrm{SVC}$ or $\mathrm{FVC}$ as the denominator in the $\mathrm{FEV}_{1} / \mathrm{VC}$ ratio, the prevalence of COPD increased, probably because of a more sensitive definition. Sixty-eight subjects who were added $\left(\mathrm{GOLDCOPD}_{\mathrm{VC}>\mathrm{FVC}}\right)$ when using the $\mathrm{VC}$ approach appeared healthier compared with the GOLDCOPD $\mathrm{FVC}_{\text {group but }}$ compared to the non-COPD group they seemed to be more obstructive and with some degree of air trapping. Not infrequently, in subjects with light-to-moderate airflow obstruction and dynamic compression, $\mathrm{FVC}$ is lower than $\mathrm{VC} .{ }^{22} \mathrm{This}$ is thought to result from closure of small airways at a higher volume during a forced expiration than when performing the SVC. Our results indicate that a definition of airflow limitation based on VC instead of FVC will identify more subjects with mild obstruction and air trapping as having COPD. To the best of our knowledge, our study is the first general population study investigating this important aspect.

Therefore, we consider that the importance of using the maximum value of SVC or FVC as a measure of VC needs 
to be examined when estimating the prevalence of COPD. In order to enable an appropriate comparison between studies, it needs to be clearly stated whether the FVC approach or the VC approach has been applied. Our study does not support the assumption that there is only a negligible difference between SVC and FVC in unselected populations. ${ }^{6}$ Rather, our findings indicate that the VC approach will result in a more sensitive definition of COPD, and probably an increased tendency to make a false-positive COPD diagnosis. An alternative conclusion is that the FVC approach may result in considerable underrecognition of subjects with COPD. Whether application of the VC concept (based on SVC) will result in more valid and reproducible estimates and better prediction of lung function decline needs to be investigated in longitudinal studies. Overall, the clinical implications of using FVC or $\mathrm{VC}$ as a denominator when assessing airway obstruction need to be further evaluated. This raises the important issue of whether a decreased $\mathrm{FEV}_{1} / \mathrm{VC}$ ratio (regardless of the definition) is just a marker of airflow limitation. For a clinically relevant diagnosis of COPD, there is further need for clinical signs or structural abnormalities. ${ }^{23}$

Previous studies have shown that the prevalence of COPD differs between populations when different definitions of COPD are used. ${ }^{24-27}$ Most studies have reported a higher prevalence of COPD using the GOLD definition compared with the LLN approach as recommended by the ERS/ATS. However, this was not the case in our study because we found a similar prevalence of COPD, regardless of the definition. This difference between studies is probably due to the comparatively narrow age interval of our study of 50-64 years because overestimation of COPD owing to the GOLD criteria increases with advancing age. Due to the different age intervals employed in many studies, the comparison of COPD prevalence between studies is difficult. A Swedish study on subjects aged $<45$ years showed similar prevalence estimates as in our study, but among subjects aged $\geq 45$ years the prevalence of COPD was considerably higher. ${ }^{24}$ In a study in the USA of participants aged 40-64 years, the prevalence of COPD was $15.6 \%$ based on the LLN approach and $19.1 \%$ based on the GOLD criteria. ${ }^{27}$ These estimates are higher than those in our study, but there was no difference with regard to the GOLD or LLN approach. In a recent Finnish study, there was also a similar prevalence of COPD, regardless of whether the GOLD or LLN criteria were applied in the age group of 40-79 years. ${ }^{25}$

One concern about the present study is the narrow age interval, 50-64 years, because the prevalence of COPD is much higher in people with more advanced age. Hence, the study has to be replicated in a wider age span in order to increase the external validity of the results. In Table 6 , it is shown that age is of importance, as a significant association between age and GOLDCOPD ${ }_{\mathrm{VC}>\mathrm{FVC}}$ is reported. Given that the average response rate in the present study was $50 \%$, another concern in nonresponse bias. It is well known that smokers are overrepresented among nonresponders, males and urban citizens, but this is mainly observed among younger subjects. ${ }^{28}$

\section{Conclusion}

The prevalence of COPD in this population-based sample of subjects aged 50-64 years was highly dependent on whether $\mathrm{VC}$ or $\mathrm{FVC}$ was used when calculating the $\mathrm{FEV}_{1} / \mathrm{VC}$ ratio. Hence, the use of only FVC when assessing airflow limitation may result in a considerable under diagnosis of subjects with mild COPD. COPD is a progressive disease, and early detection is very important to allow for immediate interventions, such as smoking cessation.

\section{Acknowledgments}

The study was supported by the Swedish Heart Lung Foundation, the Knut and Alice Wallenberg Foundation, the Swedish Research Council (VR), VINNOVA and the Swedish Council for Working Life, Health, and Welfare (FORTE), the Sahlgrenska Academy at the University of Gothenburg, Krefting Research Centre, and strategic grants from ALF/ LUA in western Sweden.

\section{Disclosure}

The authors report no conflicts of interest in this work.

\section{References}

1. Global Initiative for Chronic Obstructive Lung Disease. Available from: http://www.goldcopd.org/uploads/users/files/GOLD_Report_2015.pdf. Accessed February 5, 2015.

2. Siafakas NM, Vermeire P, Pride NB, et al. on the behalf of the Task Force. ERS Consensus statement. Optimal assessment and management of chronic obstructive pulmonary disease (COPD). Eur Respir J. 1995;8:1398-1420.

3. Pellegrino R, Viegi G, Brusasco V, et al; ATS/ERS Task Force: Standardization of Lung function testing. Interpretative strategies for lung function tests. Eur Respir J. 2005;26:948-968.

4. Redlich CA, Tarlo SM, Hankinson JL, et al; American Thoracic Society Committee on Spirometry in the occupational setting. Official American Thoracic Society technical Standards: Spirometry in the occupational setting. Am J Respir Crit Care Med. 2014;189:984-994.

5. Bakke PS, Rönmark E, Eagan T, et al; European Respiratory Society Task Force. Recommendations for epidemiological studies on COPD. Eur Respir J. 2011;38:1261-1277.

6. Vestbo J, Hurd SS, Augusti AC, et al. Global strategy for the diagnosis, management, and prevention of chronic obstructive pulmonary disease. GOLD executive summary. Am J Respir Crit Care Med. 2013;187: $347-365$. 
7. Celli BR, Decramer M, Wedzicha JA, et al; ATS/ERS Task Force for COPD Research. An official American Thoracic Society/ European Respiratory Society statement: Research questions in COPD. Eur Respir J. 2015;45:879-905.

8. Nathell L, Nathell M, Malmberg P, Larsson K. COPD diagnosis related to different guidelines and sprirometry techniques. Respir Res. 2007;8:89.

9. Brusasco V. Spirometric definition of COPD: Exercise in futility or factual debate? Thorax. 2012;67:569-570.

10. Vaz Fragoso CA, Concato J, McAvay G, et al. The ratio of $\mathrm{FEV}_{1}$ to FVC as a basis for establishing chronic obstructive pulmonary disease. Am J Respir Crit Care Med. 2010;181:446-451.

11. Quanjer PH, Tammeling GJ, Cotes JE, Pedersen OF, Peslin R, Yernault JC. Lung volumes and forced ventilatory flows. Report working party standardization of lung function tests, European Community for steel and coal. Official statement of the European Respiratory Society. Eur Respir J. 1993;6 Suppl 16:5-40.

12. Bergström G, Berglund G, Blomberg A, et al. The Swedish CArdioPulmonary BioImage Study (SCAPIS): Objectives and design. J Int Med. 2015;278(6):645-659.

13. Bestall JC, Paul EA, Garrod R, Garnham R, Jones PW, Wedzicha JA. Usefulness of the Medical Research Council (MRC) dyspnoea scale as measure of disability in patients with chronic obstructive pulmonary disease. Thorax. 1999;54:581-586.

14. Miller MR, Hankinson J, Brusasco V, et al. Standardisation of spirometry. Eur Respir J. 2005;26:319-338.

15. MacIntyre N, Crapo RO, Viegi G, et al. Standardisation of the single-breath determination of carbon monoxide uptake in the lung. Eur Respir J. 2005;26:720-735.

16. Brisman J, Kim J-L, Olin A-C, Torén K, Bake B. Spirometric reference equations for Swedish adults. Clin Physiol Funct Imaging. Epub 2016 Feb 10.

17. Hedenström H, Malmberg P, Agarwal K. Reference values for lung function tests in females. Regression equations with smoking variables. Bull Eur Physiopathol Respir. 1985;21:551-557.

18. Hedenström H, Malmberg P, Fridriksson HV. Reference values for lung function tests in men: Regression equations with smoking variables. Upsala J Med Sci. 1986;91:299-310.
19. Salorinne Y. Single-breath pulmonary diffusing capacity. Reference values and application in connective tissue diseases and in various lung diseases. Scand J Respir Dis Suppl. 1976;96:1-84.

20. Torén K, Brisman J, Järvholm B. Asthma and asthma-like symptoms in adults assessed by questionnaires. Chest. 1993;104:600-608.

21. Barros AR, Pires MB, Raposo NM. Importance of slow vital capacity in the detection of airway obstruction. J Bras Pneumonol. 2013;39: 317-322.

22. Hyatt RE, Cowl CT, Bjoraker JA, Scanlon PD. Conditions associated with an abnormal nonspecific pattern of pulmonary function tests. Chest. 2009;135:419-424.

23. Celli BR. COPD (confusion over proper diagnosis) in the zone of maximum uncertainty. Eur Respir J. 2015;46:1525-1526.

24. Lindberg A, Jonsson A-C, Rönmark E, Lundgren R, Larssson L-G, Lundbäck B. Prevalence of chronic obstructive pulmonary disease according to BTS, ERS, GOLD and ATS criteria in relation to doctor's diagnosis, symptoms, age, gender and smoking habits. Respiration. 2005; 72:471-479.

25. Kainu A, Rouhos A, Sovijärvi A, Lindqvist A, Sarna S, Lundbäck B. COPD in Helsinki, Finland: socioeconomic status based on occupation has an important impact on prevalence. Scand J Public Health. 2013; 41:570-578.

26. Wollmer P, Engström G. Fixed ratio or lower limit of normal as cutoff value for $\mathrm{FEV}_{1} / \mathrm{FVC}$ : An outcome study. Respir Med. 2013;107: 1460-1462.

27. Gupta RP, Perez-Padilla R, Marks G, Vollmer W, Menezes A, Burney P. Summarising published results from spirometric surveys of COPD: The problem of inconsistent definitions. Int J Tuberc Lung Dis. 2014;18:998-1003.

28. Rönmark EP, Ekerljung L, Lötvall J, Torén K, Rönmark E, Lundbäck B. Large scale questionnaire survey on respiratory health in west Sweden: Effects of late-response and non-response. Respir Med. 2009;103:1807-1815.
International Journal of COPD

\section{Publish your work in this journal}

The International Journal of COPD is an international, peer-reviewed journal of therapeutics and pharmacology focusing on concise rapid reporting of clinical studies and reviews in COPD. Special focus is given to the pathophysiological processes underlying the disease, intervention programs, patient focused education, and self management protocols.

\section{Dovepress}

This journal is indexed on PubMed Central, MedLine and CAS. The manuscript management system is completely online and includes a very quick and fair peer-review system, which is all easy to use. Visit http://www.dovepress.com/testimonials.php to read real quotes from published authors. 